\title{
Sesame oil in diets for lambari: Effects on growth parameters, corporal chemical composition and physiological alterations
}

\author{
Óleo de gergelim em dietas para lambari: Efeitos sobre o desempenho \\ zootécnico, composição química corporal e alterações fisiológicas
}

\author{
Mariene Miyoko Natori ${ }^{\mathrm{I}}$ Rachel Cristina Prehl Alves ${ }^{\mathrm{I}}$ Ricardo Henrique Franco de Oliveira $^{\mathrm{II}}$ \\ Julio Guerra Segura ${ }^{I}$ Elisabete Maria Macedo Viegas $^{I^{*}}$
}

\section{ABSTRACT}

The inclusion of sesame oil associated with soybean linseed and freshwater fish residue oil in the diets fed to Lambaris Astyanax altiparanae was evaluated by the growth performance parameters, body composition and possible physiological changes (GARUTTI \& BRISTSKI, 2000). The experiment was a completely randomized design in two factorial parameters tested: three oil types (soy oil (SO), linseed oil (LO) and freshwater fish residue oil (FRO)), combined or not with sesame oil (SEO), totalizing six treatments and four replications 24 cages, capacity of $0.70 \mathrm{~m}^{3}$ (density of 251 fish $\mathrm{m}^{-3}$ ). The fish (mean weight $2.35 \mathrm{~g} \pm 0.62 \mathrm{~g}$ and mean length $5.25 \mathrm{~cm} \pm 0.68 \mathrm{~cm}$ ) were fed with the experimental diets twice a day. After 75 days, the following parameters were determined: body chemical composition and fatty acid profile glycemia, liver $(L G)$ and muscle glycogen $(M G)$ levels, and lipid peroxidation (TBARS). Fish fed with diets containing SEO had higher desaturation index values of LNA while those fed with SEO combined with LO displayed reduced hepatic lipid oxidation. Inclusion of SEO improved the fatty acid profile and stability, without causing problems related to fish performance and health.

Key words: Astyanax altiparanae, fatty acids, nutrition, sesamin. RESUMO

Este trabalho fez a inclusão de óleo de gergelim associado ao óleo de soja, de linhaça e de resíduo de peixes de água doce nas dietas para avaliar o desempenho zootécnico, a composição química corporal e as possíveis alterações fisiológicas de lambari Astyanax altiparanae. $O$ delineamento experimental foi inteiramente casualizado, avaliando-se dois parâmetros: três tipos de óleo (óleo de soja (SO), óleo de linhaça (LO) e óleo de resíduo de peixe de água doce (FRO)), associado ou não ao óleo de gergelim (SEO), totalizando seis tratamentos e quatro repetições (24 tanques-rede de capacidade útil de $0,70 m^{3}$ (densidade de 251 peixes $m^{-3}$ ). Os peixes (peso médio 2,35g $\pm 0,62 \mathrm{~g}$ ) e comprimento médio de $5,25 \mathrm{~cm} \pm 0,68 \mathrm{~cm}$ ) foram alimentados duas vezes ao dia com as dietas experimentais. Após 75 dias, foram feitas as análises de composição química e perfil de ácidos graxos corporal, glicemia, glicogênio hepático $(L G)$ e muscular (MG), e peroxidação lipídica (TBARS) do tecido hepático. Os individuos que receberam dietas contendo SEO apresentaram valores mais altos de taxa de dessaturação de ácido linolênico; aqueles que receberam SEO e LO combinados demonstraram niveis reduzidos de oxidação lipídica do tecido hepático. A inclusão de SEO melhora o perfil de ácidos graxos e a estabilidade, sem provocar problemas relacionados ao desempenho e saúde dos peixes.

Palavras-chave: ácidos graxos, Astyanax altiparanae, nutrição, sesamina.

\section{INTRODUCTION}

The interest for vegetal oils as an alternative lipid source has increased (NAYLOR et al., 2000) because the inclusion of fishmeal and fish oil in the diet fed to fish led to increasing ration prices. However, it has been reported that in some marine fish species, the substitution of these ingredients can interfere with growth parameters, cause problems related to fish metabolism and consequently, the oxidative homeostasis, promoting the appearance of reactive oxygen species (ROS) (OLSVIK et al., 2011).

In tropical fish species such as Nile tilapia Oreochromis niloticus, the linolenic acid (LNA)

\footnotetext{
IDepartamento de Zootecnia, Faculdade de Zootecnia e Engenharia de Alimentos, Universidade de São Paulo (USP), 13635-900, Pirassununga, SP, Brasil. E-mail: emviegas@usp.br. "Corresponding author.

"Departamento de Ciências Básicas, Faculdade de Zootecnia e Engenharia de Alimentos, Universidade de São Paulo (USP), Pirassununga, SP, Brasil. 
included in the diets is converted to high unsaturated fatty acid (HUFA) such as the docosahexanoic acid (DHA). The LNA addition decreased the linoleic acid (LA) desaturation to HUFA n-6 due to the high affinity of the enzymes involved in desaturation and elongation processes with the n-3 fatty acids (CHEN et al., 2013). Likewise, the lambari Astyanax altiparanae (Garutti \& Bristski, 2000) is also able to convert LNA into eicosapentaenoic acid (EPA) and DHA, and LA into arachidonic acid (AA) (GONÇALVES et al., 2012; CAMPELO et al., 2014).

The therapeutic properties of sesame oil (SEO) have been verified in experiments with rats. The SEO-containing diets reduced glycemia, blood cholesterol and triglyceride levels and prevented pathological problems like formation of hepatic steatosis, and renal sepsis caused by lipopolysaccharide (LPS) (HSU et al., 2005;
GUIMARÃES \& MACEDO, 2013; PERIASAMY et al., 2014). Moreover, the lignans contained in SEO such as sesamin, episamin and sesamolin, may promote the formation of fatty acids as the DHA, from the desaturation and elongation of LNA (TRATTNER et al., 2008a; KÖSE \& YILDIZ, 2013).

Therefore, this study evaluated how the inclusion of sesame oil associated with soy oil (SO), linseed oil (LO) or FRO (freshwater fish residue oil) in diets fed to lambari Astyanax altiparanae (Garutti $\&$ Bristski, 2000) affected the growth performance parameters, body chemical composition and determined possible physiological alterations.

\section{MATERIALS AND METHODS}

Table 1 shows the formulation (COTAN et al., 2006) and composition of the extruded

Table 1 - Formulation and composition of experimental diets.

\begin{tabular}{|c|c|c|c|c|c|c|}
\hline Ingredients (\%) & $\mathrm{SO}^{*}$ & $\mathrm{LO}^{*}$ & $\mathrm{FRO}^{*}$ & $\mathrm{SO} / \mathrm{SEO}^{*}$ & $\mathrm{LO} / \mathrm{SEO}^{*}$ & $\mathrm{FRO} / \mathrm{SEO}^{*}$ \\
\hline Corn meal & 26.71 & 26.71 & 26.71 & 26.71 & 26.71 & 26.71 \\
\hline Viscera meal & 12.00 & 12.00 & 12.00 & 12.00 & 12.00 & 12.00 \\
\hline Soy meal & 13.73 & 13.73 & 13.73 & 13.73 & 13.73 & 13.73 \\
\hline Wheat meal & 22.00 & 22.00 & 22.00 & 22.00 & 22.00 & 22.00 \\
\hline Sugar cane yeast & 0.50 & 0.50 & 0.50 & 0.50 & 0.50 & 0.50 \\
\hline Rice meal & 8.00 & 8.00 & 8.00 & 8.00 & 8.00 & 8.00 \\
\hline Meat meal & 7.00 & 7.00 & 7.00 & 7.00 & 7.00 & 7.00 \\
\hline Fish meal & 5.50 & 5.50 & 5.50 & 5.50 & 5.50 & 5.50 \\
\hline Dicalcium phosphate & 0.41 & 0.41 & 0.41 & 0.41 & 0.41 & 0.41 \\
\hline Soy oil (SO) & 3.00 & - & - & 1.50 & - & - \\
\hline Linseed oil (LO) & - & 3.00 & - & - & 1.50 & - \\
\hline Fleshwater fish residue oil (FRO) & - & & 3.00 & - & - & 1.50 \\
\hline Sesame oil (SEO) & - & - & - & 1.50 & 1.50 & 1.50 \\
\hline Choline chloride & 0.10 & 0.10 & 0.10 & 0.10 & 0.10 & 0.10 \\
\hline L-Lysine & 0.11 & 0.11 & 0.11 & 0.11 & 0.11 & 0.11 \\
\hline DL-Methionine & 0.13 & 0.13 & 0.13 & 0.13 & 0.13 & 0.13 \\
\hline Antioxidant & 0.01 & 0.01 & 0.01 & 0.01 & 0.01 & 0.01 \\
\hline Antifungal & 0.10 & 0.10 & 0.10 & 0.10 & 0.10 & 0.10 \\
\hline Vitamin and mineral supplement ${ }^{1}$ & 0.50 & 0.50 & 0.50 & 0.50 & 0.50 & 0.50 \\
\hline Common salt & 0.20 & 0.20 & 0.20 & 0.20 & 0.20 & 0.20 \\
\hline Dry matter & 94.19 & 94.35 & 95.70 & 95.54 & 94.78 & 94.06 \\
\hline Crude protein & 29.39 & 29.65 & 29.09 & 29.92 & 29.29 & 29.28 \\
\hline Crude energy ( $\left.\mathrm{kcal} \mathrm{kg}^{-1}\right)$ & 4375 & 4365 & 4395 & 4365 & 4385 & 4414 \\
\hline Ether extract & 9.17 & 9.24 & 9.13 & 9.20 & 9.29 & 9.24 \\
\hline Mineral matter & 10.18 & 10.35 & 10.15 & 10.02 & 10.00 & 10.18 \\
\hline
\end{tabular}

${ }^{*}$ Treatments: Soy oil (SO 3\%), linseed oil (LO 3\%), freshwater fish residue oil (FRO 3\%), soy oil and sesame oil (SO/SEO, 1.5\%/1.5\%), linseed oil and sesame oil (LO/SEO, 1.5\%/1.5\%), freshwater fish residue oil and sesame oil (FRO/SEO, 1.5\%/1.5\%). ${ }^{1} \mathrm{Vitamin}$ and mineral supplement $(0.50 \mathrm{~g} / 100 \mathrm{~g})$ : vitamin A, 12,000UI; vitamin D3, 3,000UI; Vitamin E, 150mg; Vitamin K3, 15mg; Vitamin B2, 20mg; Vitamin B6, 17.50mg; Vitamin B12, 40mcg; Vitamin C, 300mg; Nicotinic acid, 100mg; Calcium pantotenate, 50mg; Biotin, 1.00mg; Folic acid, $6 \mathrm{mg}$; Sulphate Copper, 17.50mg; Iron sulphate, 100mg; Manganese sulfate, 50mg; Zinc sulfate, 120mg; Calcium iodide, 0,80mg; Sodium Sulfate, 0.50mg; Cobalt sulfate, 0,40mg; Inositol 125mg; Choline Chloride, 500mg; vehicle. 
experimental diets (A.O.A.C, 1990), and lipid profiles (A.O.A.C, 2005) are shown in table 2. During the experimental period of 75 days, 4,224 fish (mean weight $0.95 \mathrm{~g} \pm 0.46 \mathrm{~g}$ and mean length $4.21 \mathrm{~cm} \pm 2.77 \mathrm{~cm})$ were distributed in 24 cages (capacity $0.70 \mathrm{~m}^{3}$, density 251 fishes $\mathrm{m}^{-3}$ ). Fish were fed ad libitum twice a day (at 9:00 and 16:00). Water quality parameters such as temperature, dissolved oxygen rate, and $\mathrm{pH}$ were measured using the MultiParameter Water Quality Monitoring Meter (Horiba U-10), on alternate days. Ammonia and nitrite levels were monitored using kits and meters from Hanna Instruments, United States. Fish were weighed on days 0,35 and 75 , anesthetized with clove oil $(50 \mathrm{mg}$ $\mathrm{L}^{-1}$ of water) (PEREIRA-DA-SILVA et al., 2009) cinco grupos de 30 alevinos $(0,6 / \mathrm{ufffd} 0,1 \mathrm{~g}$ and euthanized via cranial drilling.
The sampled fish were collected from those that fasted for 24 hours prior to sampling. The following variables were determined: diet consumption (DC), apparent feed conversion (AFC), weight gain (WG), specific growth rate (SGR) and protein efficiency rate (PER). The body chemical composition of whole fish was performed following the A.O.A.C. (1990) methodology to determine dry matter (DM), crude protein (CP), mineral matter (MM), ethereal extract (EE), and crude energy (CE). A total of 25 fish were sampled per experimental unit, eviscerated and used to determine the fatty acid profile following the A.O.A.C. (2005) methodology. Lipid was extracted according to the BLIGH \& DYER (1959) methodology.

Fish glycemia levels ( $n=10$ per treatment) were measured by a portable glucose meter (Roche,

Table 2 - Lipid profile of experimental diets, expressed in $\mathrm{g} / 100 \mathrm{~g}$ of total fatty acids.

\begin{tabular}{|c|c|c|c|c|c|c|}
\hline Fatty acids & $\mathrm{SO}^{*}$ & $\mathrm{LO}^{*}$ & FRO $^{*}$ & $\mathrm{SO} / \mathrm{SEO}^{*}$ & $\mathrm{LO} / \mathrm{SEO}^{*}$ & FRO/SEO ${ }^{*}$ \\
\hline C12:0 & 0.00 & 0.06 & 0.01 & 0.00 & 0.00 & 0.00 \\
\hline C14:0 & 0.67 & 0.50 & 1.29 & 0.56 & 0.52 & 0.97 \\
\hline $\mathrm{C} 14: 1$ & 0.05 & 0.04 & 0.13 & 0.07 & 0.06 & 0.27 \\
\hline C15:0 & 0.00 & 0.09 & 0.14 & 0.11 & 0.13 & 0.14 \\
\hline C16:0 & 13.97 & 10.89 & 19.78 & 13.68 & 11.62 & 16.07 \\
\hline $\mathrm{C} 16: 1$ & 1.42 & 1.19 & 5.70 & 1.15 & 1.06 & 3.69 \\
\hline $\mathrm{C} 17: 0$ & 0.18 & 0.27 & 0.21 & 0.14 & 0.14 & 0.16 \\
\hline C18:0 & 3.51 & 4.81 & 5.65 & 4.77 & 4.7 & 5.21 \\
\hline C18:1-n9 (cis+trans) & 24.40 & 21.30 & 33.41 & 29.90 & 26.91 & 33.50 \\
\hline $\mathrm{C} 18: 2 \mathrm{n}-6$ & 49.20 & 22.69 & 26.37 & 45.06 & 31.64 & 35.15 \\
\hline C18:3n-6 & 0.00 & 0.03 & 0.51 & 0.00 & 0.00 & 0.28 \\
\hline$C 18: 3 n-3$ & 5.39 & 36.79 & 1.83 & 3.15 & 21.89 & 1.55 \\
\hline C20:0 & 0.16 & 0.15 & 0.16 & 0.28 & 0.22 & 0.29 \\
\hline$C 20: 2 n-6$ & 0.00 & 0.05 & 0.72 & 0.00 & 0.00 & 0.35 \\
\hline C20:3n-6 & 0.00 & 0.04 & 0.68 & 0.00 & 0.00 & 0.32 \\
\hline C20:4n-6 & 0.26 & 0.23 & 0.98 & 0.22 & 0.21 & 0.59 \\
\hline C20:5n-3 & 0.19 & 0.12 & 0.15 & 0.15 & 0.13 & 0.20 \\
\hline $\mathrm{C} 22: 0$ & 0.04 & 0.09 & 0.09 & 0.16 & 0.10 & 0.12 \\
\hline C22:1n-9 & 0.00 & 0.01 & 0.11 & 0.00 & 0.00 & 0.00 \\
\hline $\mathrm{C} 22: 2 \mathrm{n}-6$ & 0.00 & 0.00 & 0.05 & 0.00 & 0.00 & 0.00 \\
\hline $\mathrm{C} 24: 0$ & 0.00 & 0.05 & 0.00 & 0.00 & 0.00 & 0.00 \\
\hline C22:6n-3 & 0.20 & 0.20 & 0.64 & 0.25 & 0.25 & 0.48 \\
\hline$\Sigma \mathrm{SFA}^{1}$ & 18.53 & 16.91 & 27.33 & 19.70 & 17.43 & 22.96 \\
\hline$\Sigma \mathrm{MUFA}^{1}$ & 25.87 & 22.54 & 39.35 & 31.12 & 28.03 & 37.46 \\
\hline$\Sigma \mathrm{PUFA}^{1}$ & 55.24 & 60.15 & 31.93 & 48.83 & 54.12 & 38.92 \\
\hline $\operatorname{PUFA}_{n-6}^{1}$ & 49.46 & 23.04 & 29.31 & 45.28 & 31.85 & 36.69 \\
\hline PUFA $^{1}{ }_{n-3}$ & 5.78 & 37.11 & 2.62 & 3.55 & 22.27 & 2.23 \\
\hline PUFA $_{n-6 / n-3}^{1}$ & 8.56 & 0.62 & 11.19 & 12.75 & 1.43 & 16.45 \\
\hline
\end{tabular}

${ }^{*}$ Treatments: Soy oil (SO 3\%), linseed oil (LO 3\%), freshwater fish residue oil (FRO 3\%), soy oil and sesame oil (SO/SEO, 1.5\%/1,5\%), linseed oil and sesame oil (LO/SEO, 1.5\%/1.5\%), freshwater fish residue oil and sesame oil (FRO/SEO, 1,5\%/1,5\%). ${ }^{1}$ SFA: saturated fatty acids. MUFA: monounsaturated fatty acids. PUFA: polyunsaturated fatty acids. 
Brazil) in a $5-\mu \mathrm{L}$ blood aliquot that was collected in the caudal vein region using heparinized insulin type syringes. The glycogen was quantified in $10 \mathrm{mg}$ of liver samples (LG) $(\mathrm{n}=14$ per treatment) and $100 \mathrm{mg}$ of muscles $(\mathrm{MG})(\mathrm{n}=4$ per treatment $)$ following DUBOIS et al. (1956) modified by BIDINOTTO et al. (1997).

The thiobarbituric acid reactive substances (TBARS) were determined in hepatic tissues ( $n=6$ per treatment) following the VYNCKE (1970) methodology adapted to microplate reader by modifying the proportions described by this author. The data were submitted to ANOVA (GLM procedure), using the SAS (2002) software. The F-test results showed significant differences among treatments. The LG and TBARS data were previously treated by the SAS/LAB command.

\section{RESULTS AND DISCUSSION}

Water quality parameters such as temperature, dissolved oxygen and $\mathrm{pH}$ were kept between 23.42 and $27.07^{\circ} \mathrm{C} ; 3.62$ and $6.45 \mathrm{mg} \mathrm{L}^{-1}$; and, 6.63 and 7.23, respectively. Ammonia and nitrite levels did not exceed 0.34 and $0.41 \mathrm{mg} \mathrm{L}^{-1}$, respectively. The growth parameters and body chemical composition $(\mathrm{P}<0.05)$ were not significantly different for fish fed with diets containing SO, LO and FRO, combined or not with SEO. However, the addition of SEO to the diets affected significantly glycemia and lipid peroxidation of hepatic tissue (TBARS) (Table 3). In addition, independent of the treatment, the glycemic levels above $49 \mathrm{mg} \mathrm{DL}^{-1}$ (PEREIRA-DA-SILVA et al., 2014) indicated that the fish underwent handling and capture stress during sampling (BARTON, 2002). Addition of SEO to the LO diet increased the blood glucose levels in fish. For the lambari, the lipid sources did not change the hepatic and muscular glycogen levels significantly. However, some fatty acids may have interfered with glycogen formation, such as the oleic acid, which modifies the activity of the enzymes involved in the glucose metabolism and hepatic reserves of rainbow trout (LIBRÁN-PÉREZ et al., 2013).

The high lipid peroxidation observed in the fish fed with LO diet can be explained by the

Table 3 - Mean values of growth performance variables, body chemical composition and physiologic state.

\begin{tabular}{|c|c|c|c|c|c|c|c|c|}
\hline \multirow{2}{*}{ Growth performance } & \multirow[b]{2}{*}{$\mathrm{SO}$} & \multirow[b]{2}{*}{$\mathrm{SO} / \mathrm{SEO}$} & \multirow[b]{2}{*}{ LO } & \multirow[b]{2}{*}{$\mathrm{LO} / \mathrm{SEO}$} & \multirow[b]{2}{*}{ FRO } & \multirow[b]{2}{*}{$\mathrm{FRO} / \mathrm{SEO}$} & \multirow[b]{2}{*}{ P-value } & \multirow[b]{2}{*}{$\mathrm{RSD}^{1}$} \\
\hline & & & & & & & & \\
\hline $\mathrm{DC}^{2}(\mathrm{~g})$ & 6.89 & 7.02 & 6.71 & 6.98 & 7.46 & 7.40 & $0.51^{\mathrm{ns}}$ & 0.62 \\
\hline $\mathrm{WG}^{2}(\mathrm{~g})$ & 3.89 & 4.40 & 4.25 & 4.11 & 5.20 & 4.52 & $0.24^{\mathrm{ns}}$ & 0.74 \\
\hline $\mathrm{AFC}^{2}$ & 1.61 & 1.54 & 1.57 & 1.61 & 1.46 & 1.53 & $0.40^{\mathrm{ns}}$ & 0.11 \\
\hline $\mathrm{PER}^{2}$ & 1.93 & 2.00 & 2.13 & 1.99 & 2.40 & 2.09 & $0.39^{\mathrm{ns}}$ & 0.31 \\
\hline $\mathrm{SGR}^{2}(\% /$ Day $)$ & 1.29 & 1.4 & 1.37 & 1.33 & 1.55 & 1.42 & $0.28^{\mathrm{ns}}$ & 0.15 \\
\hline Chemical composition $(\%)$ & SO & $\mathrm{SO} / \mathrm{SEO}$ & LO & $\mathrm{LO} / \mathrm{SEO}$ & FRO & $\mathrm{FRO} / \mathrm{SEO}$ & $\mathrm{P}$-value & $\mathrm{RSD}^{1}$ \\
\hline $\mathrm{DM}^{2}$ & 34.78 & 35.46 & 35.41 & 35.51 & 35.64 & 35.41 & $0.74^{\mathrm{ns}}$ & 0.82 \\
\hline $\mathrm{CP}^{2}$ & 16.69 & 17.05 & 16.74 & 16.89 & 16.47 & 16.69 & $0.73^{\mathrm{ns}}$ & 0.53 \\
\hline $\mathrm{MM}^{2}$ & 3.78 & 3.71 & 3.89 & 3.88 & 3.9 & 3.83 & $0.56^{\mathrm{ns}}$ & 0.17 \\
\hline $\mathrm{EE}^{2}$ & 13.6 & 15.09 & 14.24 & 14.8 & 14.39 & 14.29 & $0.30^{\mathrm{ns}}$ & 0.70 \\
\hline $\mathrm{CE}^{2}\left(\right.$ kcal $\left.100 \mathrm{~g}^{-1}\right)$ & 226.3 & 232.05 & 229.47 & 230.75 & 231.58 & 228.14 & $0.87^{\mathrm{ns}}$ & 7.26 \\
\hline Physiologic state & $\mathrm{SO}$ & $\mathrm{SO} / \mathrm{SEO}$ & LO & $\mathrm{LO} / \mathrm{SEO}$ & FRO & FRO/SEO & P-value & $\mathrm{RSD}^{1}$ \\
\hline $\mathrm{MG}^{2}$ (mg glicosyl $\mathrm{g}^{-1}$ ) & 6.99 & 6.18 & 5.46 & 6.29 & 7.56 & 7.51 & $0.59^{\mathrm{ns}}$ & 1.77 \\
\hline $\mathrm{LG}^{2}$ (mg glicosyl $\left.\mathrm{g}^{-1}\right)$ & 157.06 & 103.41 & 122.05 & 128.21 & 111.03 & 106.71 & $0.31^{\mathrm{ns}}$ & 61 \\
\hline - & (3) & ------- & raction $\mathrm{E}$ & ct Oil types & EO---- & & & \\
\hline Physiologic state & SO & $\mathrm{SO} / \mathrm{SEO}$ & LO & $\mathrm{LO} / \mathrm{SEO}$ & FRO & FRO/SEO & $\mathrm{P}$-value & $\mathrm{RSD}^{1}$ \\
\hline Glycaemia (mg DL $\left.{ }^{-1}\right)$ & $104^{\mathrm{A}}$ & $98^{\mathrm{A}}$ & $90^{\mathrm{B}}$ & $106^{\mathrm{A}}$ & $100^{\mathrm{A}}$ & $100.20^{\mathrm{A}}$ & 0.03 & 13 \\
\hline $\operatorname{TBARS}^{2}\left(\mu \mathrm{mol} \mathrm{g}^{-1}\right)$ & $7.53^{\mathrm{A}}$ & $14.79^{\mathrm{A}}$ & $30.57^{\mathrm{A}}$ & $10.93^{\mathrm{B}}$ & $6.62^{\mathrm{A}}$ & $5.9^{\mathrm{A}}$ & 0.035 & 12 \\
\hline
\end{tabular}

*Treatments: Soy oil (SO 3\%), linseed oil (LO 3\%), freshwater fish residue oil (FRO 3\%), soy oil and sesame oil (SO/SEO, 1.5\%/1,5\%), linseed oil and sesame oil (LO/SEO, 1.5\%/1.5\%), freshwater fish residue oil and sesame oil (FRO/SEO, 1,5\%/1,5\%). ${ }^{1}$ Residual Standard Deviation (RSD), ${ }^{\text {ns }}$ not significant $(\mathrm{P}<0.05)$. ${ }^{* *}$ Means with different letter in the same line represent significant differences $(\mathrm{p}<0.05)$. ${ }^{2} \mathrm{Diet}$ consumption (DC), apparent feed conversion (AFC), weight gain (WG), specific growth rate (SGR), protein efficiency rate (PER), dry matter $(\mathrm{DM})$, crude protein (CP), mineral matter (MM), ethereal extract (EE), crude energy (CE), muscular glycogen (MG), liver glycogen (LG), thiobarbituric acid reactive substances (TBARS). 
probable high quantity of PUFA n-3 in the hepatic tissues. Lower quantity of PUFA n-3 in the diets reduces fish susceptibility to these oxidative reactions. This fact has been demonstrated in a seabass Lateolabrax japonicus study, in which the fish were fed with diets that contained palm oil associated with fish oil and presented lower malondialdehyde levels (MDA) (GAO et al., 2012). The ingested PUFAs are stocked in the liver and are susceptible to peroxidation due to the activation of the peroxisome proliferator-activated receptor $(\mathrm{PPAR} \alpha)$ that produces hydrogen peroxide and causes tissue damages. Thus, liver is the first organ susceptible to stress oxidative reactions and, consequently, lipid peroxidation (TAKAHASHI et al., 2002). In this research, SEO had a positive effect only on/when combined with LO.
Lipid profile of oils as shown in the lipid profile of the diets, changed significantly the saturated (SFA), monounsaturated (MUFA) and polyunsaturated (PUFA) fatty acids profiles of lambari, especially, the $\mathrm{C} 14: 0, \mathrm{C} 16: 0, \mathrm{C} 16: 1$, oleic acid (C18:1n-9), linoleic acid (LA), linolenic acid (LNA), arachidonic acid (AA), eicosapentaenoic acid (EPA) and docosahexaenoic acid (DHA) (Table 4). The addition of SEO increased the MUFA levels in fish fed the SO and LO diets. This oil is considered a source of MUFA since it contains about $46 \%$ in the lipid profile (KOCHHAR, 2002). However, the same tendency was not observed for the diets FRO combined or not with SEO due to the similar MUFA quantities in these diets composition (Table 1). The higher desaturation rates of LNA to HUFA n-3 were observed in fish that were fed with SEO in the diets.

Table 4 - Profiles of eviscerated fishes, describing main fatty acids, expressed in $\mathrm{g} / 100 \mathrm{~g}$ of total fatty acids.

\begin{tabular}{|c|c|c|c|c|c|c|c|c|}
\hline \multirow{2}{*}{ Fatty acids } & \multicolumn{3}{|c|}{----------------Oil type effect---------------- } & \multirow{2}{*}{$\mathrm{P}$ - value } & \multicolumn{2}{|c|}{----------SEO effect----------. } & \multirow{2}{*}{$\mathrm{P}$-value } & \multirow{2}{*}{$\mathrm{RSD}^{1}$} \\
\hline & $\mathrm{SO}$ & $\mathrm{LO}$ & FRO & & Without & With & & \\
\hline C12:0 & 0.08 & 0.05 & 0.06 & $0.53^{\text {ns }}$ & 0.07 & 0.06 & $0.72^{\text {ns }}$ & 0.06 \\
\hline $\mathrm{C} 16: 0$ & $20.03^{\mathrm{B}}$ & $19.45^{\mathrm{B}}$ & $21.12^{\mathrm{A}}$ & 0.001 & 20.38 & 20.01 & $0.11^{\mathrm{ns}}$ & 0.34 \\
\hline C18:0 & 8.15 & 7.89 & 7.99 & $0.23^{\mathrm{ns}}$ & 7.94 & 8.09 & $0.23^{\mathrm{ns}}$ & 0.19 \\
\hline C18:1-n9 (trans) & 0.06 & 0.09 & 0.11 & $0.53^{\mathrm{ns}}$ & 0.1 & 0.08 & $0.51^{\mathrm{ns}}$ & 0.05 \\
\hline C18:3n-6 & $0.25^{\mathrm{AB}}$ & $0.19^{\mathrm{B}}$ & $0.31^{\mathrm{A}}$ & 0.023 & 0.26 & 0.25 & $0.80^{\mathrm{ns}}$ & 0.04 \\
\hline$C 20: 2 n-6$ & 0.19 & 0.22 & 0.28 & $0.06^{\mathrm{ns}}$ & 0.23 & 0.23 & $0.94^{\mathrm{ns}}$ & 0.04 \\
\hline$C 20: 3 n-3$ & $0.00^{\mathrm{B}}$ & $0.12^{\mathrm{A}}$ & $0.00^{\mathrm{B}}$ & 0.002 & 0.05 & 0.03 & $0.35^{\mathrm{ns}}$ & 0.03 \\
\hline $\mathrm{C} 22: 6 \mathrm{n}-3\left(\mathrm{DHA}^{2}\right)$ & $0.69^{\mathrm{B}}$ & $1.00^{\mathrm{A}}$ & $0.73^{\mathrm{B}}$ & 0.02 & 0.85 & 0.77 & $0.25^{\mathrm{ns}}$ & 0.12 \\
\hline $\mathrm{SFA}^{2}$ & $29.95^{\mathrm{B}}$ & $28.94^{\mathrm{C}}$ & $30.88^{\mathrm{A}}$ & 0.003 & 30.07 & 29.78 & $0.31^{\mathrm{ns}}$ & 0.46 \\
\hline PUFA $^{2} n-6 /$ PUFA $^{2}$ n-3 & $9.55^{\mathrm{B}}$ & $2.62^{\mathrm{A}}$ & $9.26^{\mathrm{B}}$ & $<0.0001$ & $6.15^{\mathrm{B}}$ & $8.14^{\mathrm{A}}$ & 0.003 & 0.71 \\
\hline HUFA $^{2}$ n-3/LNA & $0.75^{\mathrm{B}}$ & $0.32^{\mathrm{C}}$ & $1.07^{\mathrm{A}}$ & $<0.0001$ & $0.64^{\mathrm{B}}$ & $0.80^{\mathrm{A}}$ & 0.03 & 0.09 \\
\hline Fatty acids & SO & $\mathrm{SO} / \mathrm{SEO}$ & $\begin{array}{l}\text { teraction eff } \\
\text { LO }\end{array}$ & $\begin{array}{l}\text { ect oil type } \\
\text { LO/SEO }\end{array}$ & FRO & FRO/SEO & P-value & $\mathrm{RSD}^{1}$ \\
\hline $\mathrm{C} 14: 0$ & $1.15^{\mathrm{A}}$ & $0.97^{\mathrm{B}}$ & $1.02^{\mathrm{A}}$ & $1.07^{\mathrm{A}}$ & $1.24^{\mathrm{A}}$ & $1.15^{\mathrm{A}}$ & 0.048 & 0.051 \\
\hline C18:1-n9 (cis) & $44.19^{\mathrm{B}}$ & $46.91^{\mathrm{A}}$ & $43.93^{\mathrm{A}}$ & $45.74^{\mathrm{A}}$ & $46.76^{\mathrm{A}}$ & $46.80^{\mathrm{A}}$ & 0.007 & 0.392 \\
\hline C18:2n-6 (LA $\left.{ }^{2}\right)$ & $17.84^{\mathrm{A}}$ & $16.61^{\mathrm{B}}$ & $14.31^{\mathrm{B}}$ & $15.50^{\mathrm{A}}$ & $13.48^{\mathrm{B}}$ & $15.02^{\mathrm{A}}$ & $<0.0001$ & 0.189 \\
\hline C18:3n-3 (LNA $\left.{ }^{2}\right)$ & $1.45^{\mathrm{A}}$ & $0.90^{\mathrm{B}}$ & $7.06^{\mathrm{A}}$ & $3.35^{\mathrm{B}}$ & $0.88^{\mathrm{A}}$ & $0.79^{\mathrm{A}}$ & $<0.0001$ & 0.152 \\
\hline$C 20: 3 n-6$ & $0.55^{\mathrm{A}}$ & $0.55^{\mathrm{A}}$ & $0.31^{\mathrm{B}}$ & $0.48^{\mathrm{A}}$ & $0.60^{\mathrm{A}}$ & $0.56^{\mathrm{A}}$ & 0.003 & 0.027 \\
\hline C20:4n-6 $\left(\mathrm{AA}^{2}\right)$ & $0.77^{\mathrm{A}}$ & $0.65^{\mathrm{B}}$ & $0.37^{\mathrm{B}}$ & $0.51^{\mathrm{A}}$ & $0.85^{\mathrm{A}}$ & $0.81^{\mathrm{A}}$ & 0.004 & 0.033 \\
\hline $\mathrm{C} 20: 5 n-3\left(\mathrm{EPA}^{2}\right)$ & $0.20^{\mathrm{A}}$ & $0.16^{\mathrm{A}}$ & $0.46^{\mathrm{A}}$ & $0.32^{\mathrm{B}}$ & $0.14^{\mathrm{A}}$ & $0.16^{\mathrm{B}}$ & 0.03 & 0.03 \\
\hline MUFA $^{2}$ & $47.79^{\mathrm{B}}$ & $50.16^{\mathrm{A}}$ & $47.11^{\mathrm{A}}$ & $49.18^{\mathrm{A}}$ & $51.32^{\mathrm{A}}$ & $50.90^{\mathrm{A}}$ & 0.003 & 0.37 \\
\hline PUFA $^{2}$ total & $22.05^{\mathrm{A}}$ & $19.92^{\mathrm{B}}$ & $24.12^{\mathrm{A}}$ & $21.68^{\mathrm{B}}$ & $17.32^{\mathrm{A}}$ & $18.67^{\mathrm{A}}$ & 0.003 & 0.33 \\
\hline PUFA $^{2} n-6$ & $19.40^{\mathrm{A}}$ & $18.09^{\mathrm{B}}$ & $15.21^{\mathrm{B}}$ & $16.68^{\mathrm{A}}$ & $15.27^{\mathrm{A}}$ & $16.69^{\mathrm{B}}$ & $<0.0001$ & 0.25 \\
\hline PUFA $^{2} n-3$ & $2.46^{\mathrm{A}}$ & $1.63^{\mathrm{A}}$ & $8.70^{\mathrm{A}}$ & $4.75^{\mathrm{B}}$ & $1.75^{\mathrm{A}}$ & $1.71^{\mathrm{A}}$ & $<0.0001$ & 0.20 \\
\hline HUFA $^{2}$ n-6/LA ${ }^{2}$ & $0.08^{\mathrm{A}}$ & $0.09^{\mathrm{A}}$ & $0.06^{\mathrm{A}}$ & $0.07^{\mathrm{A}}$ & $0.13^{\mathrm{A}}$ & $0.11^{\mathrm{B}}$ & 0.01 & 0.09 \\
\hline
\end{tabular}

${ }^{*}$ Treatments: Soy oil (SO 3\%), linseed oil (LO 3\%), freshwater fish residue oil (FRO 3\%), soy oil and sesame oil (SO/SEO, 1.5\%/1.5\%), linseed oil and sesame oil (LO/SEO, 1.5\%/1.5\%), freshwater fish residue oil and sesame oil (FRO/SEO, 1,5\%/1,5\%). ${ }^{1}$ Residual Standard Deviation (RSD), ${ }^{\text {ns }}$ not significant $(\mathrm{P}<0.05) .{ }^{* *}$ Means with different letter in the same line represent significant differences $(\mathrm{P}<0.05)$ ${ }^{2}$ Linoleic acid (LA), linolenic acid (LNA), araquidonic acid (AA), eicosapentaenoic acid (EPA), docosahexaenoic acid (DHA), saturated fatty acids (SFA), polyunsaturated fatty acids (PUFA), high unsaturated fatty acids (HUFA). 
Also, it was verified that the SEO efficiently promotes DHA formation in fish fed with diets with reduced LNA levels (Table 4).

The probable higher desaturation of LNA to HUFA-3 and the formation of DHA could be related to the presence of the bioactive compounds in SEO, such as sesamin. The addition of sesamin in diets containing linseed and sunflower oil modified significantly lipid metabolism and increased the DHA quantities in the white muscle of rainbow trouts Oncorhynchus mykiss and hepatocytes of Atlantic salmon Salmo salar L. (TRATTNER et al., 2008a, 2008b) hepatocytes were incubated without or with a mixture of sesamin and episesamin in order to test for possible effects on lipid metabolism. Sesamin/episesamin exposure (0.05 mM, final concentration. This compound also increased the activity of enzymes related to $\beta$ mitochondrial and peroxisomal oxidation, by activating PPAR $\alpha$ in rats, and fish as the rainbow trout Oncorhynchus mykiss and Lates calcarifer (ASHAKUMARY et al., 1999; TRATTNER et al., 2008a; ALHAZZAA et al., 2012).

\section{CONCLUSION}

The inclusion of sesame oil increased the DHA levels in fish tissues verified by the higher rates of desaturation of LNA to HUFAn-3, improving the lipid quality and promoting the oxidative stability of hepatic tissue, without altering the growth performance and fish health.

\section{ACKNOWLEDGMENTS}

The authors thanks the Fundação de Amparo à Pesquisa do Estado de São Paulo (FAPESP) for the financial support (Process $n^{\circ}$ 2012/11101-0) and Conselho Nacional de Desenvolvimento Científico e Tecnológico (CNPq), by the grant for the first author.

\section{REFERENCES}

A.O.A.C. (ASSOCIATION OF OFFICIAL ANALYTICAL CHEMISTS). Official methods of the analysis. 15.ed. Arlington, Virginia: Association of Official Analytical chemists, 1990, v.1, 1117p.

A.O.A.C. (ASSOCIATION OF OFFICIAL ANALYTICAL CHEMISTS). Official methods of analysis of the Associaton of Official Analytical Chemists. 18.ed., Gaitherburg, Mayland: AOAC, 2005; method 996.06, p20-25.

ALHAZZAA, R. et al. Sesamin modulation of lipid class and fatty acid profile in early juvenile teleost, Lates calcarifer, fed different dietary oils. Food Chemistry, v.134, p.2057-2065, 2012. Available from: <http://dx.doi.org/10.1016/j.foodchem.2012.04.004>. Accessed: Sept. 22, 2014. doi: 10.1016/j.foodchem.2012.04.004.
ASHAKUMARY, L. et al. Sesamin, a sesame lignan, is a potent inducer of hepatic fatty acid oxidation in the rat. Metabolism: Clinical and Experimental, v.48, n.10, p.1303-1313, 1999. Available from: <http://www.metabolismjournal.com/article/ S0026-0495(99)90272-X/abstract>. Accessed: Aug. 24, 2014. doi: 10.1016/S0026-0495(99)90272-X.

BARTON, B.A. Stress in fishes: a diversity of responses with particular reference to changes in circulating corticosteroids. Integrative and Comparative Biology, v.42, p.517-525, 2002. Available from: $<$ http://10.1093/icb/42.3.517>. Accessed: Dec. 21, 2013. doi: $10.1093 / \mathrm{icb} / 42.3 .517>$.

BIDINOTTO, M. et al. Hepatic glycogen and glucose in eight tropical fresh-water teleost cist for field determination of micro-samples. Boletim Tecnológico do Centro de Pesquisa e Treinamento em Aquicultura (CEPTA), v.10, p.53-70, 1997. Available from: $<$ http:// www.icmbio.gov.br/cepta/images/stories/producao_cientifica/ hepatic_1997_01.pdf $>$. Accessed: Nov. 24, 2012.

BLIGH, E.G.; DYER, W.J. A rapid method of total lipid extraction and purification. Canadian Journal of Biochemistry and Physiology, v.37, p.911-917, 1959. Available from: <http://10.1139/ o59-099>. Accessed: Apr. 21, 2014. doi: 10.1139/o59-099.

CAMPELO, D.A.V. et al. Conjugated linoleic acid in diets for lambari (Astyanax altiparanae) (Garutti \& Britski, 2000). Aquaculture Nutrition, p. n/a-n/a, 2014. Available from: $<$ http:// doi.wiley.com/10.1111/anu.12203>. Accessed: May 25, 2015. doi: 10.1111/anu.12203.

COTAN, J.L.V. et al. Níveis de energia digestível e proteína bruta em rações para alevinos de lambari tambiú. Revista Brasileira de Zootecnia, v.35, n.3, p.634-640, 2006. Available from: <http://www. scielo.br/pdf/rbz/v35n3/30051.pdf>. Accessed: Jun. 21, 2015.

CHEN, C. et al. N-3 essential fatty acids in Nile tilapia, Oreochromis niloticus: Quantification of optimum requirement of dietary linolenic acid in juvenile fish. Aquaculture, v.416-417, p.99-104, 2013. Available from: $<$ http://10.1016/j.aquaculture.2013.09.003>. Accessed: Sept. 23, 2014. doi: 10.1016/j.aquaculture.2013.09.003.

GAO, J. et al. Effects of dietary palm oil supplements with oxidized and non-oxidized fish oil on growth performances and fatty acid compositions of juvenile Japanese sea bass, Lateolabrax japonicus. Aquaculture, v.324-325, p.97-103, 2012. Available from: <http:// www.sciencedirect.com/science/article/pii/S0044848611008477>. Accessed: Sept. 24, 2014. doi: 10.1016/j.aquaculture.2011.10.031.

GONÇALVES, L.U. et al. Effect of the inclusion of fish residue oils in diets on the fatty acid profile of muscles of males and females lambari (Astyanax altiparanae). Revista Brasileira de Zootecnia, v.41, p.1967-1974, 2012. Available from: <http://10.1590/S151635982012000900001>. Accessed: Feb. 23, 2014. doi: 10.1590/ S1516-35982012000900001.

GUIMARÃES, R.; MACEDO, M. Sesame and flaxseed oil: nutritional quality and effects on serum lipids and glucose in rats. Food Science and techonology, v.33, n.1, p.209-217, 2013. Available from: <http://dx.doi.org/10.1590/S0101-20612013005000029>. Accessed: Jul. 21, 2014. doi: 10.1590/S0101-20612013005000029.

HSU, D.-Z. et al. Effect of sesame oil on oxidative-stressassociated renal injury in endotoxemic rats: involvement of nitric oxide and proinflammatory cytokines. Shock (Augusta, Ga.), v.24, n.3, p.276-280, 2005. Available from: <http://10.1097/01. 
shk.0000172366.73881.c7>. Accessed: Aug. 22, 2013. doi: 10.1097/01.shk.0000172366.73881.c7.

IDE, T. et al. Interaction of dietary fat types and sesamin on hepatic fatty acid oxidation in rats. Biochimica et Biophysica Acta Molecular and Cell Biology of Lipids, v.1682, p.80-91, 2004. Available from: $<$ http://10.1016/j.bbalip.2004.02.001>. Accessed: Nov. 24, 2012. doi: 10.1016/j.bbalip.2004.02.001.

KOCHHAR, S.P. Sesame, rice-bran and flaxseed oils. In: GUNSTONE, F.D. (Ed.). Vegetable oils in food technology: composition, propreties and uses. Florida: Blackwell, 2002. p.297-326.

KÖSE, I.; YILDIZ, M. Effect of diets containing sesame oil on growth and fatty acid composition of rainbow trout (Oncorhynchus mykiss). Journal of Applied Ichthyology, v.29, p.1318-1324, 2013. Available from: <http://10.1111/jai.12184>. Accessed: Mar 23, 2015. doi: 10.1111/jai.12184.

LIBRÁN-PÉREZ, M. et al. Response of hepatic lipid and glucose metabolism to a mixture or single fatty acids: possible presence of fatty acid-sensing mechanisms. Comparative Biochemistry and Physiology - A Molecular and Integrative Physiology, v.164, n.1, p.241248, 2013. Available from: <http://10.1371/journal. pone.0059507>. Accessed: Dec. 21, 2014. doi: 10.1371/journal. pone. 0059507 .

NAYLOR, R.L. etal.Effect of aquaculture on worldfish supplies. Nature, v.405, p.1017-1024, 2000. Available from: <http://10.1038/35016500>. Accessed: Nov. 21, 2009. doi: 10.1038/35016500.

OLSVIK, P.A. et al. Hepatic oxidative stress in Atlantic salmon (Salmo salar L.) transferred from a diet based on marine feed ingredients to a diet based on plant ingredients. Aquaculture Nutrition, v.17, p.424436, 2011. Available from: <http://10.1111/j.1365-2095.2010.00778 $\mathrm{x}>$. Accessed: Feb. 12, 2012. doi: 10.1111/j.1365-2095.2010.00778.x.

PEREIRA-DA-SILVA, E.M. et al. Menthol as anaesthetic for lambari Astyanax altiparanae (Garutti \& Britski 2000): attenuation of stress responses. Aquaculture Research, p. n/a-n/a, 2014. Available from: <http://10.1111/are.12599>. Accessed: Jun. 23, 2014. doi: 10.1111/are.12599.
PEREIRA-SILVA, E.M. et al. Efeito anestésico do óleo de cravo em alevinos de lambari. Ciência Rural, v.39, p.1851-1856, 2009. Available from: <http://10.1590/S010384782009005000127>. Accessed: Mar. 23, 2012. doi: 10.1590/ S0103-84782009005000127.

PERIASAMY, S. et al. Sesame oil mitigates nutritional steatohepatitis via attenuation of oxidative stress and inflammation: a tale of two-hit hypothesis. Journal of Nutritional Biochemistry, v.25, n.2, p.232-240, 2014. Available from: <http://10.1016/j. jnutbio.2013.10.013>. Accessed: Mar. 22, 2015. doi: 10.1016/j. jnutbio.2013.10.013.

SAS INSTITUTE. SAS/STAT user's guide. Cary, NC, 2002. Version 9.2.

TAKAHASHI, M. et al. Fish oil feeding alters liver gene expressions to defend against PPARalpha activation and ROS production. American Journal of Physiology. Gastrointestinal and liver physiology, v.282, p.G338-G348, 2002. Available from: $<$ http://10.1152/ajpgi.00376.2001>. Accessed: Nov. 23, 2014. doi: 10.1152/ajpgi.00376.2001.

TRATTNER, S. et al. Sesamin increases alpha-linolenic acid conversion to docosahexaenoic acid in atlantic salmon (Salmo salar L.) hepatocytes: role of altered gene expression. Lipids, v.43, p.999-1008, 2008a. Available from: <http://10.1007/ s11745-008-3229-7>. Accessed: May 21, 2012. doi: 10.1007/ s11745-008-3229-7.

TRATTNER, S. et al. Sesamin supplementation increases white muscle docosahexaenoic acid (DHA) levels in rainbow trout (Oncorhynchus mykiss) fed high alpha-linolenic acid (ALA) containing vegetable oil: metabolic actions. Lipids, v.43, p.989997, 2008b. Available from: <http://10.1007/s11745-008-3228-8>. Accessed: Apr. 22, 2012. doi: 10.1007/s11745-008-3228-8.

VYNCKE, W. Direct determination of the thiobarbituric acid value in trichloracetic acid extracts of fish as a measure of oxidative rancidity. Fatte Seifen Anstrichmittel, v.72, p.1084-1087, 1970. Available from: <http://10.1002/lipi.19700721218>. Accessed: Nov. 21, 2012. doi: 10.1002/lipi.19700721218. 